\section{New Ravidomycin Analogues, FE35A and FE35B, Apoptosis Inducers Produced by Streptomyces rochei}

\author{
Noriyuki Yamashita, Kazuo Shin-ya, \\ Kazuo Furihata ${ }^{\dagger}$, YoICHI HaYaKaWa \\ and Haruo SETO* \\ Institute of Molecular and Cellular Biosciences, \\ The University of Tokyo, \\ ${ }^{\dagger}$ Division of Agriculture and Agricultural Life Science, \\ The University of Tokyo, \\ Bunkyo-ku, Tokyo 113-0032, Japan
}

(Received for publication August 24, 1998)

Apoptosis is a physiological process by which cells undergo controlled cell death accompanied by nuclear condensation and fragmentation without loss of membrane integrity ${ }^{1,2)}$. This phenomenon is generally observed during the development of lymphocytes and neutrophils ${ }^{3)}$ in a hematopoietic system. In addition, neoplastic cells are often subjected to apoptosis when treated with anti-cancer drugs ${ }^{4,5)}$. Since interleukin-1 $\beta$ converting enzyme (ICE) proteases, particularly caspase3 , are activated during apoptosis, their overexpression inducing cell apoptosis is considered to play an important role in the initiation of apoptosis in variety of cell systems even though their molecular mechanisms are not well understood.

During the course of our screening program for new antitumor antibiotics capable of inducing apoptosis in tumor cells, we isolated 6-hydroxytetrangulol ${ }^{6)}$ as a caspase- 3 inducer. Further investigation has resulted in the isolation of two novel substances belonging to the benzo[d]naphtho[1,2-b]pyran-6-one group. We report herein the fermentation, isolation and structure determination of these two products designated FE35A (1) and FE35B (2).

The producing organism of $\mathbf{1}$ and $\mathbf{2}$ identified as Streptomyces rochei 3218-GM2, which was isolated from a soil sample collected in Iou-island, Tokyo, was cultivated at $27^{\circ} \mathrm{C}$ for 5 days in two 50 -liter jar fermenters containing 30 liters of a medium consisting of soluble starch $2.5 \%$, soybean meal $1.5 \%$, dry yeast $0.2 \%$ and calcium carbonate $0.4 \%(\mathrm{pH} \mathrm{7.0)}$.

The mycelial cake obtained from the cultured broth (60 liters) was extracted with acetone. After concentrated in vacuo, the extract was partitioned between EtOAc and $\mathrm{H}_{2} \mathrm{O}$ at $\mathrm{pH} 7.0$ and the organic layer was dried over $\mathrm{Na}_{2} \mathrm{SO}_{4}$. The filtrate of the cultured broth was adsorbed on a Diaion HP-20 column. The column was washed with $\mathrm{H}_{2} \mathrm{O}$ and $50 \% \mathrm{MeOH}$, and active materials

Table 1. Physico-chemical properties of FE35A (1) and FE35B (2).

\begin{tabular}{lll}
\hline & FE35A (1) & FE35B (2) \\
\hline Appearance & yellow powder & yellow powder \\
{$[\alpha]^{23}{ }_{D}$} & $-41^{\circ}(c 0.05, \mathrm{MeOH})$ & $-98^{\circ}\left(c 0.05, \mathrm{CHCl}_{3}\right)$ \\
$\mathrm{MP}\left(\mathrm{dec},{ }^{\circ} \mathrm{C}\right)$ & $228 \sim 231$ & $239 \sim 242$ \\
Formula & $\mathrm{C}_{30} \mathrm{H}_{31} \mathrm{NO}_{9}$ & $\mathrm{C}_{31} \mathrm{H}_{31} \mathrm{NO}_{10}$ \\
HRFAB-MS $(m / z)$ & $550.2099(\mathrm{M}+\mathrm{H})^{+}$ & $578.2054(\mathrm{M}+\mathrm{H})^{+}$ \\
$\quad$ calcd. & 550.2078 & 578.2026 \\
$\mathrm{UV} \lambda$ max $(\varepsilon)$ & $245(35100), 277(\mathrm{sh})$, & $245(35000), 277(\mathrm{sh})$, \\
$\quad$ in MeOH & $285(32900), 321(13100)$, & $285(32500), 321(13000)$, \\
& $334(11200), 350(9400)$, & $334(11000), 350(9200)$, \\
& $393(12900)$ & $393(12900)$ \\
IR v max $(\mathrm{KBr}) \mathrm{cm}^{-1}$ & $3400,1710,1620,1605$, & $3400,1720,1620,1605$, \\
& 1590 & 1590 \\
Solubility & & \\
$\quad$ soluble in & $\mathrm{MeOH}, \mathrm{DMSO}$ & $\mathrm{CHCl}, \mathrm{MeOH}, \mathrm{DMSO}$ \\
$\quad$ insoluble in & $\mathrm{H}_{2} \mathrm{O}$, hexane & $\mathrm{H}_{2} \mathrm{O}, \mathrm{hexane}$ \\
\hline
\end{tabular}


Table 2. ${ }^{13} \mathrm{C}(125 \mathrm{MHz})$ and ${ }^{1} \mathrm{H}(500 \mathrm{MHz})$ chemical shift data of FE35A $\left(\mathbf{1}\right.$, in $\left.\mathrm{MeOH}-d_{4}\right)$,

$\mathrm{B}\left(2\right.$, in $\left.\mathrm{CDCl}_{3}\right)$ and ravidomycin (in $\left.\mathrm{CDCl}_{3}\right)$.

\begin{tabular}{|c|c|c|c|c|c|c|}
\hline \multirow[b]{2}{*}{ No. } & \multicolumn{2}{|c|}{ FE35A (1) } & \multicolumn{2}{|c|}{ FE35B (2) } & \multicolumn{2}{|c|}{ Ravidomycin } \\
\hline & $\delta_{\mathrm{C}}$ & $\delta_{\mathrm{H}}$ & $\delta_{\mathrm{c}}$ & $\delta_{\mathrm{H}}$ & $\delta_{c}$ & $\delta_{\mathrm{H}}$ \\
\hline 1 & 155.8 & & 154.7 & & 154.7 & \\
\hline 2 & 113.3 & $6.99(\mathrm{~d}, 8.3)$ & 112.6 & $6.98(\mathrm{~d}, 8.5)$ & 112.4 & $7.04(\mathrm{~d}, 8.3)$ \\
\hline 3 & 130.8 & $7.92(\mathrm{~d}, 8.3)$ & 129.5 & $7.78(\mathrm{~d}, 8.5)$ & 129.5 & $7.98(\mathrm{~d}, 8.3)$ \\
\hline 4 & 126.7 & & 124.5 & & 125.2 & \\
\hline $4 a$ & 124.5 & & 125.5 & & 125.2 & \\
\hline $4 b$ & 143.8 & & 142.5 & & 142.9 & \\
\hline 6 & 161.9 & & 160.7 & & 160.6 & \\
\hline $6 a$ & 123.3 & & 122.2 & & 122.2 & \\
\hline 7 & 120.3 & $7.97(\mathrm{~d}, 1.2)$ & 120.2 & $8.08(\mathrm{~d}, 1.6)$ & 119.7 & $8.02(\mathrm{~d}, 1.6)$ \\
\hline 8 & 140.5 & & 138.9 & & 138.6 & \\
\hline 9 & 115.5 & $7.50(\mathrm{~d}, 1.2)$ & 114.3 & $7.33(\mathrm{~d}, 1.6)$ & 113.8 & $7.25(\mathrm{~d}, 1.6)$ \\
\hline 10 & 158.9 & & 157.4 & & 157.1 & \\
\hline $10 \mathrm{a}$ & 123.5 & & 123.9 & & 123.4 & \\
\hline $10 \mathrm{~b}$ & 115.4 & & 114.2 & & 113.9 & \\
\hline 11 & 103.1 & $8.43(\mathrm{~s})$ & 102.7 & $8.45(s)$ & 102.1 & $8.28(\mathrm{~s})$ \\
\hline 12 & 153.4 & & 152.2 & & 151.8 & \\
\hline $12 \mathrm{a}$ & 117.0 & & 116.5 & & 116.3 & \\
\hline 13 & 136.5 & $6.82(\mathrm{dd}, 17.5,10.5)$ & 135.2 & $6.78(\mathrm{dd}, 17.0,11.0)$ & 135.2 & $6.76(\mathrm{dd}, 17.2,10.5)$ \\
\hline \multirow[t]{2}{*}{14} & 117.0 & $6.00(\mathrm{~d}, 17.5)$ & 116.6 & $5.91(\mathrm{~d}, 17.0)$ & 116.2 & $5.91(\mathrm{~d}, 17.2)$ \\
\hline & & $5.43(\mathrm{~d}, 10.5)$ & & $5.41(\mathrm{~d}, 11.0)$ & & $5.44(\mathrm{~d}, 10.5)$ \\
\hline 10-OMe & 56.9 & $4.10(\mathrm{~s})$ & 56.4 & $4.07(\mathrm{~s})$ & 56.0 & $4.00(\mathrm{~s})^{\S}$ \\
\hline 12-OMe & 56.7 & $4.08(\mathrm{~s})$ & 56.4 & $4.08(\mathrm{~s})$ & 55.9 & $4.01(\mathrm{~s})^{\S}$ \\
\hline $1^{\prime}$ & 81.3 & $6.03(\mathrm{~d}, 8.8)$ & 79.9 & $5.85(\mathrm{~d}, 9.3)$ & 80.5 & $5.85(\mathrm{~d}, 9.4)$ \\
\hline $2^{\prime}$ & 67.5 & $4.46(\mathrm{dd}, 9.7,8.8)$ & 71.2 & $4.08(\mathrm{dd}, 9.4,9.3)$ & 65.4 & $4.44(\mathrm{dd}, 10.2,9.4)$ \\
\hline $3^{\prime}$ & 62.8 & $4.71(\mathrm{dd}, 9.7,2.2)$ & 57.1 & $4.48(\mathrm{~m})$ & 69.6 & $3.08(\mathrm{dd}, 10.2,3.0)$ \\
\hline $4^{\prime}$ & 74.2 & $3.92(\mathrm{~d}, 2.2)$ & 74.2 & $5.26(\mathrm{~d}, 2.2)$ & 69.4 & $5.56(\mathrm{~d}, 3.0)$ \\
\hline $5^{\prime}$ & 77.0 & $4.40(\mathrm{q}, 6.4)$ & 73.8 & $4.51(\mathrm{q}, 6.4)$ & 75.0 & $4.49(\mathrm{q}, 6.4)$ \\
\hline $6^{\prime}$ & 17.0 & $1.20(\mathrm{~d}, 6.4)$ & 16.9 & $1.09(\mathrm{~d}, 6.4)$ & 16.8 & $1.05(\mathrm{~d}, 6.4)$ \\
\hline 3'-NMe & 34.0 & $3.24(\mathrm{~s})$ & & & 40.8 & $2.51(\mathrm{~s})$ \\
\hline 3'-NCOMe & 22.4 & $2.17(\mathrm{~s})$ & 23.3 & $2.01(\mathrm{~s})$ & & \\
\hline 3'-NCOMe & 174.6 & & 172.0 & & & \\
\hline 4'-COMe & & & 20.9 & $2.17(\mathrm{~s})$ & 21.6 & $2.11(\mathrm{~s})$ \\
\hline $4^{\prime}-C O \mathrm{Me}$ & & & 172.5 & & 170.8 & \\
\hline $1-\mathrm{OH}$ & & & 9.78 & & & $9.77(\mathrm{~s})$ \\
\hline 3'-NH & & & 6.05 & (brd, 7.0) & & \\
\hline
\end{tabular}

Chemical shifts are expressed in ppm relative to TMS as an internal standard.

$\S$ : Assignments may be interchangeable.

were eluted with $\mathrm{MeOH}$. The EtOAc extract and the column eluate were combined and concentrated to dryness, and the residue was subjected to silica gel column chromatography developed with $\mathrm{CHCl}_{3}-\mathrm{MeOH}$ $(50: 1)$ to give active fractions. They were combined and applied to a Toyopearl HW-40 column packed with $\mathrm{MeOH}$ to yield a mixture of $\mathbf{1}$ and 2. This material was subjected to preparative HPLC using ODS with $45 \%$ acetonitrile and $50 \mathrm{~mm}$ disodium citrate $(\mathrm{pH} 4.0)$ to give fractions containing pure $\mathbf{1}$ or $\mathbf{2}$. After concentration in vacuo, the aqueous residue containing 1 was extracted with EtOAc three times. The combined extract was concentrated to give a pure sample of $\mathbf{1}(2.0 \mathrm{mg})$ as a yellow amorphous powder. In a similar manner, $\mathbf{2}$ was obtained at the yield of $2.3 \mathrm{mg}$.

The physico-chemical properties, and the ${ }^{1} \mathrm{H}$ and ${ }^{13} \mathrm{C}$ NMR data of 1 and 2 are summarized in Table 1 and 2, respectively. 1 was soluble in $\mathrm{MeOH}$ and DMSO, slightly soluble in $\mathrm{CHCl}_{3}$ and EtOAc, but insoluble in water and $n$-hexane. 2 was soluble in $\mathrm{CHCl}_{3}, \mathrm{MeOH}$ and DMSO but insoluble in water and $n$-hexane. The molecular formulae of $\mathbf{1}$ and $\mathbf{2}$ were established as 
Fig. 1. Structures of FE35A (1), FE35B (2) and ravidomycin.

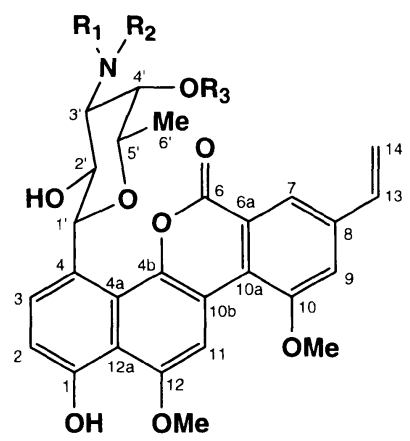

FE35A (1): $\quad R_{1}=M e, R_{2}=A c, \quad R_{3}=H$ FE35B (2): $\quad R_{1}=H, \quad R_{2}=A c, \quad R_{3}=A c$ Ravidomycin : $\mathrm{R}_{1}=\mathrm{Me}, \mathrm{R}_{2}=\mathrm{Me}, \mathrm{R}_{3}=\mathrm{Ac}$

$\mathrm{C}_{30} \mathrm{H}_{31} \mathrm{NO}_{9}$ and $\mathrm{C}_{31} \mathrm{H}_{31} \mathrm{NO}_{10}$, respectively, from HRFAB-MS and NMR spectral analyses. IR adsorptions at $3400 \mathrm{~cm}^{-1}$ and $1710(1720$ in 2$) \mathrm{cm}^{-1}$ suggested the presence of hydroxyl and ester functions in $\mathbf{1}$ and $\mathbf{2}$. Since the UV and visible spectra of $\mathbf{1}$ and $\mathbf{2}$ resembled those of ravidomycins ${ }^{7,8)}$, chrysomycins ${ }^{9)}$ and gilvocarcins ${ }^{10)}$, the chromophore of $\mathbf{1}$ and $\mathbf{2}$ was revealed to be benzo[d]naphtho[1,2-b]pyran-6-one as shown in Fig. 1. Long-range couplings from aromatic protons observed in the HMBC spectra also supported the chromophore structure of 1 and $\mathbf{2}$ (Fig. 2).

The structure of 1 was elucidated by NMR analysis as follows. In the HMBC spectrum of $\mathbf{1}$, a vinyl proton $13-\mathrm{H}(6.82 \mathrm{ppm})$ coupled to exo methylene protons $14-\mathrm{H}$ $(6.00 \mathrm{ppm} ; 17.5 \mathrm{~Hz}, 5.43 \mathrm{ppm} ; 10.5 \mathrm{~Hz})$, was long-range coupled to aromatic carbons C-7 (120.3 ppm), C-8 (140.5 ppm) and C-9 (115.5 ppm). Thus, the connectivity between the aglycone and the vinyl residue was proved as shown in Fig. 2. Likewise, two methoxy groups were linked to C-10 (158.9 ppm) and C-12 (153.4 ppm). These partial structures together with similar UV and visible spectral features between 1 and ravidomycin suggested the presence of the same chromophore in both compounds. The ${ }^{1} \mathrm{H}$ and ${ }^{13} \mathrm{C}$ NMR data summarized in Table 2 corroborated this conclusion. The structural difference between ravidomycin and $\mathbf{1}$ was ascribed to the sugar moiety. NMR spectral analysis of the sugar group of 1 revealed a $C$-glycosylated 6-deoxyhexopyranose. The sequence from $1^{\prime}-\mathrm{H}(6.03 \mathrm{ppm})$ to $4^{\prime}-\mathrm{H}$ (3.92 ppm) through $2^{\prime}-\mathrm{H}(4.46 \mathrm{ppm})$ and $3^{\prime}-\mathrm{H}(4.71 \mathrm{ppm})$ was established by ${ }^{1} \mathrm{H}-{ }^{1} \mathrm{H}$ COSY spectral analysis. The connectivity between C-4' (74.2 ppm), C-5' (77.0 ppm)
Fig. 2. NMR analyses of $\mathbf{1}$ and $\mathbf{2}$.

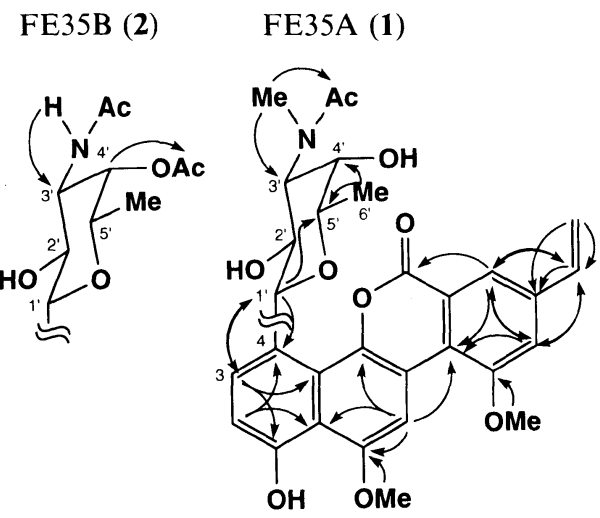

$\frown:{ }^{1} \mathrm{H}-{ }^{13} \mathrm{C}$ long-range couplings

and C-6' $(17.0 \mathrm{ppm})$ was determined by long-range couplings from $6^{\prime}-\mathrm{H}$ methyl protons $(1.20 \mathrm{ppm})$ to $\mathrm{C}-4^{\prime}$ and $\mathrm{C}-5^{\prime}$. The tetrahydropyran moiety was elucidated by a long-range coupling from $1^{\prime}-\mathrm{H}$ to $\mathrm{C}-5^{\prime}$. Long-range couplings from a methylamino proton $3^{\prime}$ - $\mathrm{NMe}(3.42$ ppm) to C-3' and an acetyl carbon $3^{\prime}-\mathrm{NCO}$ (174.6 ppm) were attributed to the existence of an $N, N$-acetyl methylamino group at C-3' position. Large coupling constants of $2^{\prime}-\mathrm{H}(J=8.8,9.7 \mathrm{~Hz})$ revealed the relative configuration of 1'-, 2'- and 3'- protons on the tetrahydropyran to be axial-axial. A small coupling constant $(J=2.2 \mathrm{~Hz})$ between $3^{\prime}-\mathrm{H}$ and $4^{\prime}-\mathrm{H}(3.92 \mathrm{ppm})$ showed the relative configuration to be axial-equatorial. On the other hand, negligible coupling between $\mathrm{H}-4^{\prime}$ and $\mathrm{H}-5^{\prime}(4.40 \mathrm{ppm})$ indicated that $4^{\prime}-\mathrm{H}$ and $5^{\prime}-\mathrm{H}$ have an equatorial and an axial configuration, respectively ${ }^{7,8)}$. The ${ }^{13} \mathrm{C}$ chemical shift of C-6' $(17.0 \mathrm{ppm})$ similar to that of ravidomycin $(16.8 \mathrm{ppm})$ also supported the relative configuration of $5^{\prime}-\mathrm{H}$ to be axial. Finally, the $C$-glycosidic moiety was combined to the $\mathrm{C}-4$ position by long-range couplings from $\mathrm{I}^{\prime}-\mathrm{H}$ to $\mathrm{C}-3$ (130.8 ppm) and $\mathrm{C}-4$ (126.7 ppm), and $3-\mathrm{H}$ to $\mathrm{C}-1^{\prime}$. Thus, the remaining hydroxyl residue was substituted to the C-1 (155.8 ppm) position as seen in ravidomycin. Other long-range couplings observed in the HMBC spectrum together with UV and visible spectra ascribed the structure of $\mathbf{1}$ as shown in Fig. 1.

The analyses of the HMBC spectral data of 2 confirmed the existence of the same chromophore as those of $\mathbf{1}$ and ravidomycins. In addition, a tetrahydropyran moiety was linked to the chromophore at $\mathrm{C}-4$ position through a $C$-glycosidic linkage. The differences between $\mathbf{1}$ and $\mathbf{2}$ are ascribed to the substituents at C-3' and C-4' (69.4 ppm) 
on the tetrahydropyran moiety. The methylamino signal in 1 was replaced by an amino proton $(6.05 \mathrm{ppm})$ which was long-range coupled to C-3' (69.6 ppm) and an amino acyl carbon (172.0 ppm) in 2. Low field shift of $\mathrm{H}-\mathbf{4}^{\prime}$ $(5.26 \mathrm{ppm})$ revealed the sugar moiety acetylated at the C-4' position of 2. Other NMR data including longrange couplings from a phenolic hydroxyl proton $1-\mathrm{OH}$ (9.78 ppm) to aromatic carbons C-1 (154.7 ppm), C-2 (112.6ppm) and C-12a (116.5 ppm) established the structure of 2 as shown in Fig. 2.

1 and 2 showed cytotoxicity against U937 leukemia cells with the $\mathrm{IC}_{50}$ values of 3.7 and $4.6 \mathrm{~nm}$, respectively. In order to investigate the relationship between the cytotoxic activities of these compounds and the ability to induce caspase-3, we employed a system using DEVD-AMC ( $N$-acetyl-Asp-Glu-Val-Asp-7-amino-4methylcoumarin) as the caspase-3 substrate ${ }^{6)}$. Caspase-3 induced by apoptotic agents cleaves DEVD-AMC to AMC in this assay system enabling estimation of the caspase- 3 activity is estimated by measuring the UV and visible absorption of AMC. In this evaluation system, $\mathbf{1}$, 2 and ravidomycin induced a caspase- 3 like activity in U937 leukemia cells at concentrations higher than $200 \mathrm{nM}$ for 3 hours after administrations.

Ravidomycin and other coumarin-related antitumor agents have been reported as potent inhibitors of human topoisomerase II ${ }^{11)}$. Dimethylepipodophyllotoxin VP-16 and adriamycin are known as clinical important antitumor drugs that also inhibit eukaryotic topoisomerase II, which were reported to induce the CPP32 like proteases in tumor cells ${ }^{12)}$. Further studies on detailed biological activities of $\mathbf{1}$ and $\mathbf{2}$ are now underway.

\section{Acknowledgments}

This work was supported in part by a Grant in Aid for Scientific Research (C) to K.S. This work was also supported in part by a Grant in Aid for Scientific Research and a Grant in Aid for Scientific Research on Priority Areas, The Ministry of Education, Science, Sports and Culture, Japan, and Research for Future, Japan Society for the Promotion of Science.

\section{References}

1) Duvall E. \& A, H. Wyllie: Death and the cell. Immunol. Today 7: $115 \sim 119,1986$

2) Steller, H.: Mechanisms and genes of cellular suicide. Science 267: 1445 1449, 1995

3) Cohen, J.; R. C. Duke, V. A. FadoK \& K. S. Sellins: Apoptosis and programmed cell death in immunity. Annu. Rev. Immunol. 10: 267 293, 1992

4) Thompson, C. B.: Apoptosis in the pathogenesis and treatment of disease. Science 267: 1456 1462, 1995

5) Fisher, D. E.: Apoptosis in cancer therapy: Crossing the threshold. Cell 78: 539 542, 1994

6) Yamashita, N.; T. Harada, K. Shin-ya \& H. Seto: 6-Hydroxytetrangulol, a new CPP32 protease inducer by Streptomyces sp. J. Antibiotics 51: 79 81, 1998

7) Findlay, J. A.; J. S. LiU, L. Radics \& S. Rakhit: The structure of ravidomycin. Can. J. Chem. 59: 3018 3020, 1981

8) Narita, T.; M. Matsumoto, K. Mogi, K. Kukita, R. Kawahara \& T. Nakashima: Deacetylravidomycin $N$-oxide, a new antibiotic. Taxonomy and fermentation of the producing organism and isolation, structure and biological properties of the antibiotic. J. Antibiotics 42: $347 \sim 356,1989$

9) Weiss, U.; K. Yoshihira, R. J. Highet, R. J. White \& T. T. WEI: The chemistry of the antibiotics chrysomycin A and B. Antitumor activity of chrysomycin A. J. Antibiotics 35: 1194 1201, 1982

10) Takahashi, K.; M. Yoshida, F. Tomita \& K. Shirahata: Gilvocarcins, new antitumor antibiotics. 2. Structural elucidation. J. Antibiotics 34: 271 275, 1981

11) LORICO, A \& B. H. LONG: Biochemical characterisation of elsamicin and other coumarin-related antitumor agents as potent inhibitors of human topoisomerase II. Eur. J. Cancer 29A: 1985 1991, 1993

12) Mashima, T.; M. Naito, S. Kataoka, H. Kawai \& T. Tsuruo: Aspartate-based inhibitor of interleukin-1 beta-converting enzyme prevents antitumor agentinduced apoptosis in human myeloid leukemia U937 cells. Biochem. Biophys. Res. Commun. 209: 907 915, 1995 